Jurnal Litbang Vol. XI, No. 2 Desember 2015: 143-150

\title{
KENAKALAN REMAJA AWAL DI LINGKUNGAN SEKOLAH DITINJAU DARI KETIDAKHADIRAN ORANG TUA KARENA MERANTAU
}

\section{DELINQUENCY ON EARLY ADOLESCENT IN THE SCHOOLS REVIEWED FROM THE ABSENCE OF PARENTS BECAUSE OF TEMPORAL MIGRATION}

\author{
Siti Qorrotu Aini \\ Kantor Penelitian dan Pengembangan Kabupaten Pati \\ Email: ainiqurrotu85@gmail.com
}

Naskah Masuk: 25 September 2015 Naskah Revisi: 9 Oktober 2015 Naskah Diterima: 16 Oktober 2015

\begin{abstract}
Early adolescent phase that coincided with the beginning of secondary school age have characteristics that emotionally still volatile because of the influence of hormonal changes in adolescents. This forms a distinctive characteristic in early adolescence which includes aspects social behavior, moral, religious, affective, cognitive and personality. The reviewed purpose is to explain the potential of early adolescent delinquency in the school environment on students whose parents migrated for temporary. Adolescent phase needs nurturing, guidance, direction and supervision. The parents roles is needed for the success of adolescent development. Adolescent who left by their parents for temporal migration have psychosocial youth impact in their school life. Adolescent beside studied academicly also required to comply with the applicable rules at school. Adolescent who are left for temporal migration and have psychosocial problem, forms of delinquency includes substance abuse such as alcohol, behavioral problems includes coming late, ditching, not doing homework, words are rude, alcohol, viewing pornography, fighting, courting school environment, write inappropriate words on the walls of the bathroom and indications brawl.
\end{abstract}

Keywords: early adolescence, delinquency at school, temporary migrated parents

\begin{abstract}
ABSTRAK
Fase remaja awal yang bertepatan dengan usia sekolah menengah memiliki karakteristik yang secara emosional masih bergejolak karena pengaruh perubahan hormonal dalam diri remaja. Hal ini membentuk karakteristik yang khas pada masa remaja awal yang meliputi aspek perilaku sosial, moral, religi, afeksi, kognitif dan kepribadian. Tujuan penulisan untuk menjelaskan potensi kenakalan remaja awal di lingkungan sekolah pada siswa yang orang tuanya merantau. Fase remaja membutuhkan pengasuhan, bimbingan, arahan dan pengawasan. Peran orang tua sangat dibutuhkan untuk keberhasilan perkembangan anak remaja. Remaja yang ditinggal orang tuanya merantau memiliki dampak psikososial remaja dalam kehidupannya bersekolah. Remaja, selain belajar secara akademis juga dituntut untuk mematuhi aturan yang berlaku disekolah. Remaja yang ditinggal merantau dan memiliki masalah psikosial, bentuk-bentuk kenakalannya meliputi penyalahgunaan zat berupa minuman keras, masalah perilaku meliputi terlambat, membolos, tidak mengerjakan tugas/PR, perkataan yang kasar, minuman keras, melihat pornografi, berkelahi, pacaran dilingkungan sekolah, menulis kata-kata tidak pantas di tembok kamar mandi dan indikasi tawuran.
\end{abstract}

Kata kunci : remaja awal, kenakalan di sekolah, orang tua yang merantau 


\section{PENDAHULUAN}

Istilah merantau menurut kamus besar bahasa Indonesia memiliki arti berlayar (mencari penghidupan) disepanjang rantau (dari satu sungai ke sungai lain dsb). Merantau dapat diartikan dengan orang yang meninggalkan teritorial asal dan menempati teritorial baru. Mereka mencari mata pencaharian baru di rantau untuk memenuhi kebutuhan hidup mereka (Setyawan, 2015). Istilah lain dari merantau adalah migrasi.

Fenomena migrasi terjadi hampir di seluruh wilayah Indonesia. Provinsi Jawa Tengah mempunyai banyak tenaga kerja yang melakukan migrasi baik migrasi ke dalam negeri maupun ke luar negeri. Hal ini dapat dilihat dari data Badan Pusat Statistik (BPS) menunjukkan banyaknya TKI AKAN (Tenaga Kerja Indonesia Antar Kerja Antar Negara) pada tahun 2014 yaitu sebanyak 92.587 jiwa. Adapun banyaknya perantau ke dalam negeri berdasarkan data penempatan tenaga kerja melalui mekanisme AKAD (Antar Kerja Antar Daerah) pada tahun 2013 adalah sebanyak 16.686 jiwa. Sebagian besar perantau di Provinsi Jawa Tengah merupakan TKI AKAN. TKI AKAN lebih banyak merantau ke luar negeri dengan tujuan Malaysia dan Singapura. Kondisi ini terjadi baik perantau laki-laki maupun perempuan. Berdasarkan data penempatan tenaga kerja melalui mekanisme AKAD (Antar Kerja Antar Daerah) menurut sub sektor di Jawa Tengah pada tahun 2013, perantau ke dalam negeri mayoritas bekerja dalam sektor perkebunan, tekstil, dan bidang elektronik, dengan tujuan Jawa Barat, DKI Jakarta, Riau, Sumatra, Kalimantan, dan lain-lain (BPS Provinsi Jawa Tengah, 2014).

Pati merupakan kabupaten di Propinsi Jawa Tengah dengan perantau terbanyak keenam setelah Cilacap, Kendal, Brebes, Banyumas, dan Tegal. Jumlah perantau di Kabupaten Pati berdasarkan data Dinsosnakertrans (2014) sebanyak 882 jiwa, Jumlah tersebut dengan rincian penempatan berdasarkan data TKI AKAN sebanyak 639 jiwa dan TKI AKAD sebanyak 243 jiwa. Jumlah tersebut belum termasuk tenaga kerja antar daerah yang tidak terdaftar.

Keluarga khususnya orang tua memiliki peranan yang sangat penting dalam pengajaran nilai-nilai bagi anak pada usia remaja. Remaja sudah mulai berani untuk menunjukkan dirinya tetapi masih mudah untuk terpengaruh oleh lingkungan sosialnya. Oleh karena itu pada usia ini, anak membutuhkan perhatian khusus dan masih membutuhkan bimbingan dan dukungan dalam menghadapi masalahnya sendiri (Gunarsa, 2001). Orang tua perantau melakukan komunikasi dengan keluarga yang ditinggalkan, terutama anak biasanya melalui telepon. Hal ini menyebabkan peran orang tua kurang dalam pengajaran, pengasuhan, dan bimbingan kepada anak secara langsung. Ketidakhadiran orang tua karena merantau juga akan menyebabkan kedekatan dan kelekatannya antara anak dan orang tua kurang terbentuk.

Kelekatan pada masa kanak-kanak dengan orang tua akan berpengaruh pada banyak pengalaman remaja di kemudian harinya serta dapat mempengaruhi remaja dalam menghadapi situasi-situasi yang berpotensi menyebabkan stres dan problem-problem psikososial (Geldard \& Geldard, 2011). Problem psikososial merupakan problem yang muncul pada anak, dalam hal ini remaja yang berhubungan dengan hubungan sosial yang mencakup faktor-faktor psikologis (Chaplin, 2011).

Remaja awal berusia berkisar antara 13-15 tahun. Anak-anak pada fase 
remaja awal, pemahaman dirinya masih bersifat fluktuatif yang ditandai dengan emosi yang belum stabil. Hal ini berkaitan dengan perubahan hormonal dimana remaja mengalami perubahan jasmani yang sangat pesat dan perkembangan intelektual yang sangat intensif sehingga minat anak pada dunia luar sangat besar. Remaja awal tidak mau dianggap kanak-kanak lagi namun belum bisa meninggalkan pola kekanakkanakannya. Selain itu pada masa ini remaja sering merasa sunyi, ragu-ragu, tidak stabil, tidak puas dan merasa kecewa (Kartono, 1990).

Usia remaja bertepatan dengan usia Sekolah Menengah Pertama (SMP). Posisi remaja di lingkungan sekolah sebagai siswa. Siswa remaja diharapkan mampu mengembangkan potensi yang dimiliki secara optimal di sekolah. Siswa tidak hanya dirangsang secara intelektual, akan tetapi juga dituntut untuk berperilaku sesuai dengan norma dan aturan yang ada di sekolah. Keberhasilan pendidikan anak di sekolah tidak terlepas dari hubungan yang baik antara sekolah, keluarga dan masyarakat.

Orang tua yang merantau seringkali mempercayakan pendidikan anak sepenuhnya ke sekolah, sedangkan orang tua kurang dapat berperan dalam mengasuh, membimbing dan memberikan pengawasan secara langsung terhadap remaja. Kondisi yang demikian, dapat memunculkan permasalahan psikososial/ kenakalan remaja ketika di lingkungan sekolah. Secara umum jika siswa tidak dapat berkembang dengan baik sesuai dengan kebutuhannya akan menimbulkan perilaku menyimpang yang kita kenal dengan kenakalan remaja.

Tujuan penulisan ini adalah untuk menjelaskan potensi kenakalan remaja awal di lingkungan sekolah pada siswa yang orang tuanya merantau.
KARAKTERISTIK REMAJA AWAL

Makmun (2000) menyebutkan ciriciri umum remaja awal dilihat dari beberapa aspek, yaitu:

Aspek Perilaku Sosial meliputi:

a. Kecenderungan ambivalensi keinginan menyendiri dan keinginan bergaul dengan banyak teman tetapi bersifat temporer;

b. Kebergantungan yang kuat kepada kelompok sebaya disertai semangat konformitas yang tinggi;

c. Adanya ambivalensi antara keinginan bebas dari dominasi pengaruh orang tua dengan kebutuhan bimbingan dan bantuan dari orang tua.

\section{Aspek Moralitas}

a. Mulai menguji kaidah-kaidah atau sistem nilai etis dengan kenyataannya dalam perilaku sehari-hari dengan sikap dan cara berfikirnya yang kritis;

b. Mengidentifikasi dirinya dengan tokoh-tokoh moralitas yang dipandang tepat dengan tipe idolanya.

\section{Aspek Religiusitas}

a. Mulai mempertanyakan secara kritis dan spektis mengenai keberadaan dan sifat kemurahan dan keadilan Tuhan;

b. Penghayatan kehidupan keagamaan sehari-hari didasarkan pertimbangan tuntutan yang memaksa dari luar dirinya; dan

c. Masih mencari dan mencoba menemukan pegangan hidup.

\section{Aspek Afektif, Kognitif dan} Kepribadian

a. Lima kebutuhan dasar (fisik, rasa aman, afiliasi sosial, penghargaan, perwujudan diri) mulai menunjukkan arah kecenderungan-kecenderungan;

b. Reaksi, reaksi dan ekspresi emosinya masih labil dan belum terkendali seperti pernyataan marah, gembira atau kesedihannya mungkin masih dapat berubah-ubah silih berganti dalam tempo yang cepat; 
c. Kecenderungan-kecenderungan arah sikap mulai tampak (teoritis, ekonomis, estetis, politis, sosial dan religius) meskipun masih dalam taraf eksplorasi dan coba-coba; dan

d. Merupakan masa kritis dalam rangka menghadapi kritis identitasnya yang sangat dipengaruhi oleh kondisi psikososialnya yang akan membentuk kepribadiannya.

Dengan karakteristik seperti di atas siswa yang tergolong usia remaja apabila tidak mendapatkan bimbingan yang baik mudah terjerumus pada perbuatan yang merugikan dirinya sendiri atau terjerumus dalam kenakalan remaja (siswa).

\section{DAMPAK \\ ORANGTUA MERANTAU TERHADAP ANAK YANG DITINGGAL}

Orang tua yang merantau secara positif dapat mempengaruhi kualitas hidup anak-anak. Anak-anak hidup dalam kondisi yang lebih baik, termasuk seperti rumah yang diperbaiki dan dilengkapi. Anak-anak memiliki sumber daya keuangan untuk membeli pakaian mahal dan berbagai barang, untuk menghibur diri sendiri. Selain itu anakanak memiliki keuntungan untuk menikmati berbagai barang seperti komputer pribadi, perekam audio, telepon seluler dan lainnya, yang biasanya sulit bagi teman-teman sebayanya untuk mendapatkan barang tersebut (UNICEF dalam Prihantini, 2015). Komunikasi menjadi suatu hal yang penting bagi perantau untuk sekedar menanyakan kabar atau memantau anaknya, biasanya perantau lakukan dengan menggunakan telepon

Orang tua yang merantau memiliki dampak negatif di samping dampak positif. Dampak negatif terutama terhadap anak yang ditinggalkan. Bakker, Elings-Pels, dan Reis dalam
Prihantini (2015) menyebutkan dampak dari remaja yang ditinggal orang tuanya merantau, remaja memiliki problem psikososial yang diakibatkan dari tidak terbentuknya kelekatan anak dengan orang tua.

UNICEF dalam Prihantini (2015) memaparkan beberapa dampak psikologis pada anak-anak di Moldova yang ditinggal merantau orang tuanya, antara lain kurang mampu dalam mengembangkan kemampuan pribadi dalam mengatasi kesulitan di kehidupan dewasanya, seperti kemandirian dalam pengambilan keputusan, kepercayaan diri, manajemen waktu dan pengendalian emosi. Dampak dalam bidang intelektual, seperti hilangnya minat sekolah dan kemunduran prestasi akademik. Kurangnya motivasi untuk belajar dapat memiliki konsekuensi negatif pada pendidikan anak tersebut. Kerentanan terhadap penyalahgunaan narkoba yang disebabkan oleh tekanan dari teman-teman sebayanya. UNICEF secara lebih lanjut memaparkan bahwa perasaan anak-anak yang ditinggal orang tuanya merantau dapat menimbulkan sebuah kompleks rendah diri. Hal tersebut dapat memiliki konsekuensi negatif pada keluarga anak-anak di masa depan.

Penelitian yang dilakukan oleh Bakker, Elings-Pels and Reis dalam Prihantini (2015) mengemukakan bahwa kegiatan merantau di Karibia memiliki dampak negatif besar pada keluarga, khususnya pada anak. Anak-anak yang telah ditinggalkan berada pada situasi rentan secara psikososial dan pendidikan mereka. Mereka berada pada risiko yang lebih tinggi dan lebih rentan terhadap pelecehan, penelantaran dan eksploitasi termasuk kekerasan seksual, pekerja anak dan perdagangan. Anak-anak yang ditinggalkan banyak yang menderita depresi dan rendah diri yang dapat 
mengakibatkan masalah perilaku seperti terlibat dalam kekerasan dan kejahatan atau melarikan diri dari rumah.

\section{BENTUK-BENTUK KENAKALAN SISWA YANG ORANGTUANYA MERANTAU}

Kenakalan remaja pada dasarnya menunjuk pada suatu bentuk perilaku remaja yang tidak sesuai dengan normanorma yang hidup di dalam masyarakatnya. Kartono (2003) memberikan batasan kenakalan remaja merupakan gejala sakit secara sosial pada anak-anak dan remaja yang disebabkan oleh bentuk pengabaian sosial, sehingga mereka mengembangkan bentuk tingkah laku yang menyimpang. Perilaku anakanak ini menunjukkan kurang atau tidak adanya konformitas terhadap normanorma sosial. Keputusan Menteri Sosial (Kepmensos RI No. 23/HUK/1996) menyebutkan anak nakal adalah anak yang berperilaku menyimpang dari norma-norma sosial, moral dan agama, merugikan keselamatan dirinya, mengganggu dan meresahkan ketenteraman dan ketertiban masyarakat serta kehidupan keluarga dan atau masyarakat.

Penelitian Prihantini (2015) menunjukkan problem psikososial remaja yang orang tuanya merantau. Hasil penelitian menunjukkan bahwa terdapat 9 (sembilan) bentuk problem psikososial yang muncul pada remaja laki-laki adalah membolos, bertengkar, main biliar, merokok, minum minuman keras, berjudi, main kartu, berkelahi, dan tawuran. Problem psikososial yang dialami remaja perempuan adalah membolos, bertengkar, berkelahi, dan main kartu.

Secara sederhana kenakalan remaja dibagi dalam dua bentuk, yaitu:
1) Penyalahgunaan zat yaitu minuman keras; dan 2) Masalah perilaku.

\section{Penyalahgunaan Zat}

Masalah penyalahgunaan zat pada remaja yang orang tuanya merantau, yaitu minum minuman keras. Papalia, Olds dan Fieldman (2009) menyebutkan mengenai faktor pendorong remaja untuk melakukan penyalahgunaan narkoba dan zat terlarang diantaranya adalah karakteristik temperamen, kontrol dorongan yang buruk, pengaruh keluarga, masalah perilaku seperti agresivitas, kurangnya komitmen terhadap pendidikan, penolakan teman sebaya, bergaul dengan pengguna narkoba dan zat terlarang, memiliki teman-teman yang menggunakan dan mentolerir penggunaan narkoba, merasa diasingkan dan memiliki sifat sebagai pemberontak, memandang positif terhadap pengguna narkoba serta mencoba narkoba sejak usia dini.

Pengaruh keluarga seperti yang dijelaskan Papalia, Olds dan Fieldman (2009) menjadi salah satu faktor pendorong terbentuknya remaja yang minum minuman keras. Faktor pendorong lainnya yang sesuai dengan penjelasan Papalia, Olds dan Fieldman (2009) adalah bergaul dengan teman yang merokok dan minum minuman keras.

\section{Masalah Perilaku}

Bentuk kenakalan remaja dalam masalah perilaku meliputi terlambat, membolos, tidak mengerjakan tugas/PR, perkataan yang kasar, minuman keras, melihat pornografi, berkelahi, pacaran di lingkungan sekolah, menuliskan katakata tidak pantas di tembok kamar mandi dan indikasi tawuran. Santrock (2012) menyatakan bahwa kenakalan remaja disebabkan oleh beberapa hal, diantaranya adalah remaja yang berasal dari status sosial yang rendah, peran 
keluarga, seperti kurangnya dukungan dari keluarga terlebih orang tua, kurangnya pengawasan dari orang tua, dan memiliki atau bergaul dengan teman sebaya yang terlibat dalam kenakalan remaja. Peran keluarga seperti dukungan dari keluarga terlebih orang tua, serta kurangnya pengawasan dan pengasuhan dari orang tua menjadi salah satu faktor terbentuknya kenakalan remaja.

Kurangnya pengasuhan, pengawasan dan dukungan dari orang tua seperti yang telah dijelaskan tersebut, remaja akan mencari dukungan lain yaitu misalnya dari pergaulan subjek atau teman subjek. Pemaparan Santrock (2012) yang meyebutkan bahwa memiliki atau bergaul dengan teman sebaya yang terlibat dalam kenakalan remaja akan menyebabkan remaja juga ikut melakukan kenakalan tersebut. Remaja yang orang tuanya merantau memiliki pergaulan dalam berteman yang kurang baik. Teman-teman dari remaja yang orang tuanya merantau merupakan anak dari perantau juga.

\section{KESIMPULAN DAN SARAN}

\section{Kesimpulan}

Fase remaja awal yang bertepatan dengan usia sekolah menengah memiliki karakteristik yang masih fluktuatif secara emosional karena pengaruh perubahan hormonal dalam diri remaja. Hal ini membentuk karakteristik yang khas pada masa remaja awal yang meliputi aspek perilaku sosial, moral, religi, afeksi, kognitif dan kepribadian.

Fase ini masih membutuhkan pengasuhan, bimbingan, arahan dan pengawasan. Peran orang tua sangat dibutuhkan untuk keberhasilan perkembangan anak remaja. Remaja yang ditinggal orang tuanya merantau memiliki dampak psikososial yang ditunjukkan oleh sejumlah hasil penelitian diantaranya kurang mampu dalam mengembangkan kemampuan pribadi dalam mengatasi kesulitan di kehidupan dewasanya, seperti kemandirian dalam pengambilan keputusan, kepercayaan diri, manajemen waktu dan pengendalian emosi. Dalam bidang intelektual, seperti hilangnya minat sekolah dan kemunduran prestasi akademik. Kurangnya motivasi untuk belajar dapat memiliki konsekuensi negatif pada pendidikan anak tersebut. Kerentanan terhadap penyalahgunaan narkoba yang disebabkan oleh tekanan dari teman-teman sebayanya, merasa rendah diri, dan hal tersebut dapat memiliki konsekuensi negatif pada keluarga anak-anak di masa depan.

Remaja dalam kehidupannya bersekolah, selain belajar akademis juga dituntut untuk mematuhi aturan yang berlaku disekolah. Remaja yang ditinggal merantau dan memiliki masalah psikosial memiliki bentuk-bentuk kenakalan diantaranya penyalahgunaan zat berupa minuman keras dan masalah perilaku meliputi terlambat, membolos, tidak mengerjakan tugas/PR, perkataan yang kasar, minuman keras, melihat pornografi, berkelahi, pacaran di lingkungan sekolah, menuliskan katakata tidak pantas di tembok kamar mandi dan indikasi tawuran.

\section{Saran}

1. Orang Tua: Meskipun berada di perantauan, tetap terlibat aktif untuk berkomunikasi dengan anak untuk memberikan arahan dan bimbingan moral, sosial dan agama. Jika anak benar-benar sendirian di rumah sebaiknya ditempatkan pada lingkungan yang mendukung. Misalnya: pondok, ataupun sekolah berasrama. Orang tua mengajarkan anak tanggungjawab dengan memberi syarat ketika meminta barang mewah yang diinginkan. 
2. Guru Bimbingan dan Konseling:

Berteman dengan siswa di jejaring sosial. Hal ini bermanfaat untuk mengontrol indikasi permasalahan siswa yang sedang dihadapi melalui ungkapan-ungkapan atau ekspresi tulisan di media sosial. Pemberdayaan dan penghargaan potensi anak melalui kegiatan ekstra ataupun organisasi intra sekolah. Guru diharapkan proaktif berkomunikasi langsung terhadap orang tua dengan meminta kontak orang tua untuk meminimalisir pesan yang tidak sampai karena disembunyikan oleh anak/wali siswa yang mewakili. Guru Bimbingan dan Konseling melakukan home visit untuk mengetahui kondisi lingkungan siswa di rumah.

3. Instansi sekolah: Sebagai keluarga kedua bagi remaja diharapkan menerapkan manajemen sekolah, serta budaya sekolah yang ramah anak. Mengajak orang tua dan atau wali siswa untuk bersama-sama mendidik anak karena keberhasilan siswa didik adalah tanggungjawab bersama antara sekolah, orang tua dan masyarakat.

4. Masyarakat: Ikut menjadi pengontrol dan pengarah remaja terutama yang sedang bermasalah.

\section{Pemerintah melalui Badan} Pemberdayaan Perempuan dan Keluarga Berencana: Secara aktif memberikan sosialisasi mengenai pengasuhan yang tepat, terutama bagi anak-anak yang ditinggal merantau dan diasuh oleh pihak ketiga. Berupaya merubah persepsi bahwa pendidikan anak hanya menjadi tanggungjawab sekolah sebagai instansi formal pendidikan.

\section{DAFTAR PUSTAKA}

Chaplin, J. P. 2011. Kamus Lengkap Psikologi. Terjemahan oleh
Kartini Kartono. 2011. Jakarta: Rajawali Pers.

Badan Pusat Statistik Propinsi Jawa Tengah. 2014. Banyaknya TKI AKAN (Tenaga Kerja Indonesia Antar Kerja Antar Negara) Menurut Kabupaten/Kota di Jawa Tengah Tahun Anggaran 20102014.

http://jateng.bps.go.id/LinkTabelSt atis/view/id/1178, diakses tanggal 16 September 2015.

2014. Banyaknya

Pencari Kerja Menurut Pendidikan Tertinggi yang Ditamatkan di Jawa Tengah Tahun 2009 - 2013 Penempatan Tenaga Kerja Melalui Mekanisme AKAD, (Antar Kerja Antar Daerah) Menurut Sub Sektor di Jawa Tengah Tahun Anggaran 2009 - 2013. http://jateng.bps.go.id/linkTabelSt atis/view/id/649, diakses tanggal 18 September 2015.

Dinas Sosial Tenaga Kerja dan Transmigrasi Kabupaten Pati. 2014. Laporan Informasi Pasar Kerja. Pati.

Geldard, K., dan Geldard, D. 2011. Konseling Remaja: Pendekatan Proaktif untuk anak muda. Yogyakarta: Pustaka Pelajar

Gunarsa, S. D., Y. S. D, Gunarsa. 2001. Psikologi Praktis: Anak, Remaja, dan Keluarga. Jakarta: PT. BPK Gunung Mulia.

Kamus Besar Bahasa Indonesia. Pengertian Merantau. http://kamusbahasaindonesia.org/ merantau/mirip, diakses tanggal 4 September 2015.

Kartono, K. 1990. Psikologi Perkembangan Anak. Bandung: CV. Mandari. 
Kartono, K. 2003. Patologi Sosial, Kenakalan Remaja. Jakarta: Raja Grafindo Persada.

Keputusan Menteri Sosial (Kepmensos RI No. 23/HUK/1996. 1996. https://www.kemsos.go.id/modules .php? name = glosariumkesos\&lette $r=a$, diakses tanggal 18 September 2015

Makmun, A. S. 2000. Psikologi Pendidikan. Bandung: Remaja Rosdakarya.

Papalia, D. E., S. W. Olds., R. D. Feldman. 2008. Human Development: Perkembangan Manusia, Edisi 10 Buku 2. Terjemahan oleh Brian Marswendy. 2009. Jakarta: Salemba Humanika.

Prihantini, D., S. Lestari. 2015. Problem Psikososial pada Remaja yang Orang Tuanya Merantau. http://eprints.ums.ac.id/26791/11/ 02._Naskah_Publikasi.pdf, diakses tanggal 26 September 2015.

Santrock, John. W. 2012. Life Span Development: Perkembangan Masa Hidup edisi ketigabelas Jilid 1. Terjemahan oleh Benedictine Widyasinta. 2012. Jakarta: Erlangga.
Setyawan, I. 2015. Merantau bagi Masyarakat Minangkabau Periode 1990-2000-an.

http://www.kompasiana.com/keret aunto.blogspot.com/merantaubagi-masyarakat-minangkabauperiode-1990-2000an_5518ec87a33311b812b65970, diakses tanggal 21 September 2015.

\section{BIODATA PENULIS}

Siti Qorrotu Aini, lahir 5 Agustus 1985 di kota Pati Jawa Tengah. Sarjana (S1) Universitas Diponegoro Semarang Jurusan Psikologi Tahun 2009. Bekerja sebagai peneliti di Kantor Penelitian dan Pengembangan Kabupaten Pati. 